\title{
Paenibacillus antarcticus sp. nov., a novel psychrotolerant organism from the Antarctic environment
}

\author{
Mª Jesús Montes, Elena Mercadé, Núria Bozal and Jesús Guinea
}

Correspondence

Jesús Guinea

jguinea@farmacia.far.ub.es
Laboratori de Microbiologia, Facultat de Farmacia, Universitat de Barcelona, Av. Joan XXIII s/n, 08028 Barcelona, Spain

\begin{abstract}
An endospore-forming strain, $20 \mathrm{CM}^{\top}$, was isolated from Antarctic sediment and identified as a member of the genus Paenibacillus on the basis of phenotypic and phylogenetic analyses. The organism stained Gram-variable and was facultatively anaerobic. Strain $20 \mathrm{CM}^{\top}$ was psychrotolerant, growing optimally at $10-15^{\circ} \mathrm{C}$. Like other Paenibacillus species, it contained anteiso- $\mathrm{C}_{15 \text { : o }}$ as the major cellular fatty acid. The DNA G $+\mathrm{C}$ content was $40 \cdot 7 \mathrm{~mol} \%$. 16S rRNA gene sequence analysis placed strain $20 \mathrm{CM}^{\top}$ within the Paenibacillus cluster, with a similarity value of $99.5 \%$ to Paenibacillus macquariensis DSM $2^{\top}$. DNA-DNA hybridization experiments between the Antarctic isolate and $P$. macquariensis DSM $2^{\top}$ revealed a reassociation value of $47 \%$, indicating that strain $20 \mathrm{CM}^{\top}$ and $P$. macquariensis $\mathrm{DSM} 2^{\top}$ belong to different species. Based on evaluation of morphological, physiological, chemotaxonomic and phylogenetic analyses, a novel species, Paenibacillus antarcticus sp. nov., is proposed; the type strain is $20 \mathrm{CM}^{\top}$ (= LMG $22078^{\top}=$ CECT $\left.5836^{\top}\right)$.
\end{abstract}

Based on 16S rRNA analysis, Ash et al. (1993) proposed the genus Paenibacillus to accommodate a group of aerobic or facultatively anaerobic rod-shaped, endospore-forming bacteria. Many Bacillus species were transferred to the genus Paenibacillus based on a comparison of their 16S rRNA gene sequences with other members of the Bacillaceae (Ash et al., 1993; Heyndrickx et al., 1995, 1996a, b; Shida et al., 1997a; Pettersson et al., 1999). Traditionally, Gram-positive, rodshaped, endospore-forming bacteria have been classified in the genus Bacillus (Claus \& Berkeley, 1986). However, in recent years, the genus Bacillus has been separated into several distinct genera, such as Alicyclobacillus (Wisotzkey et al., 1992), Aneurinibacillus and Brevibacillus (Shida et al., 1996), Halobacillus (Spring et al., 1996), Paenibacillus (Ash et al., 1993), Amphibacillus (Niimura et al., 1990), Filobacillus (Schlesner et al., 2001), Geobacillus (Nazina et al., 2001), Virgibacillus (Heyndrickx et al., 1998), Gracilibacillus and Salibacillus (Wainø et al., 1999) and Ureibacillus (Fortina et al., 2001). Antarctica is a source of novel Bacillus species (Logan et al., 2000, 2002, 2004a); novel

Published online ahead of print on 20 February 2004 as DOI 10.1099/ ijs.0.63078-0.

The GenBank/EMBL/DDBJ accession number for the16S rRNA gene sequence of Paenibacillus antarcticus $20 \mathrm{CM}^{\top}$ is AJ605292.

A table giving fatty acid composition (Table A) and figures showing electron micrographs and a phylogenetic tree (Figs A and B, respectively) are available as supplementary material in IJSEM Online. members of the genus Paenibacillus have also been described recently in this environment (Logan et al., 2004b).

According to Ash et al. (1993), members of the genus Paenibacillus produce ellipsoidal endospores in swollen sporangia. The cell wall shows structures typical of Grampositive bacteria, but usually stains negatively. The DNA $\mathrm{G}+\mathrm{C}$ contents range from 40 to $54 \mathrm{~mol} \%$ and anteiso- $\mathrm{C}_{15: 0}$ is the major cellular fatty acid. Some members of the genus produce antibacterial compounds (Slepecky \& Hemphill, 1991) and iturin-like antifungal antibiotics (Chung et al., 2000). One distinctive characteristic of the genus Paenibacillus is the ability to excrete a wide variety of enzymes that degrade natural biopolymers such as alginate, chondroitin, chitin, curdlan, starch (Kanzawa et al., 1995; Nakamura, 1987; Chung et al., 2000; van der Maarel et al., 2000) and other polysaccharides (Priest et al., 1988).

In this study, the taxonomic status of strain $20 \mathrm{CM}^{\mathrm{T}}$ was investigated using a combination of phenotypic characterization, sequencing of the $16 \mathrm{~S}$ rRNA gene, DNA base composition, DNA-DNA hybridization and cellular fatty acid composition analysis. Strain $20 \mathrm{CM}^{\mathrm{T}}$ is proposed as a representative of a novel species, Paenibacillus antarcticus sp. nov.

Strain $20 \mathrm{CM}^{\mathrm{T}}$ was isolated from sediment collected in Chlorite Lake on the Byers Peninsula of Livingston Island (South Shetland Islands, Antarctica). Sample aliquots were 
removed with a platinum loop and diluted in a saline solution containing ( $\left.\mathrm{g} \mathrm{l}^{-1}, \mathrm{pH} 7\right)$ : $\mathrm{NaCl}, 0 \cdot 56 ; \mathrm{KCl}, 0 \cdot 27$; $\mathrm{CaCl}_{2}, 0 \cdot 03$; and $\mathrm{NaHCO}_{3}, 0 \cdot 01$. Trypticase soy agar (TSA; ADSA) plates were inoculated with loopfuls of several sample dilutions using the streak-plate method to obtain well-isolated colonies. Plates were incubated for 4 days at $15^{\circ} \mathrm{C}$. Isolates were maintained aerobically on TSA slopes at $4^{\circ} \mathrm{C}$ and also at $-80^{\circ} \mathrm{C}$ on cryo-beads.

Morphology, cell size and shape of spores were determined by scanning (Hitachi model H 2300) and transmission (Hitachi model $\mathrm{H} 600 \mathrm{AB}$ ) electron microscope observations of cells grown in trypticase soy broth (TSB; ADSA) at $15{ }^{\circ} \mathrm{C}$. Motility was determined by phase-contrast microscopy (Olympus model CHS). Gram staining was performed according to Hucker \& Conn (1923). Two alternative methods, the $\mathrm{KOH}$ test and the L-alanine aminopeptidase assay (Manafi \& Kneifel, 1990), were also used. Oxidase, catalase and urease activities, methyl red reaction, VogesProskauer, nitrate reduction, indole production, citrate utilization, and hydrolyses of casein, lecithin, gelatin, DNA, tyrosine, starch and Tween 80 were determined following Cowan \& Steel (1993). Dihydroxyacetone production, phenylalanine deamination and growth in the presence of lysozyme $(0.1$ and $0.001 \%$, w/v) were determined as described by Claus \& Berkeley (1986). Acid production from carbohydrates and additional tests were determined using the API 50CH and API 20E system (bioMérieux). Tolerance to $\mathrm{NaCl}$ was measured on nutrient agar (ADSA) containing $0-10 \%(\mathrm{w} / \mathrm{v}) \mathrm{NaCl}$. Plates were incubated at $15^{\circ} \mathrm{C}$ for 30 days. The temperature range for growth was determined on TSA incubated for 14 days at 4, 10, 15, 20, 25, 30, 31, 32, 33 and $37^{\circ} \mathrm{C}$. Anaerobic growth was determined on TSB plus agar-agar ( $1.5 \%$; ADSA) by incubation in an anaerobic chamber at $15{ }^{\circ} \mathrm{C}$ for 5 days.

Cells were Gram-variable, rod-shaped $(0 \cdot 7 \times 2.5 \mu \mathrm{m})$ and motile by means of peritrichous flagella (see Fig. Aa, b; available as supplementary material in IJSEM Online). Strain $20 \mathrm{CM}^{\mathrm{T}}$ produced ellipsoidal spores in swollen sporangia in the subterminal or terminal region of the cell (see Fig. Ac, d, e; available as supplementary material in IJSEM Online). Colonies grown on TSA at $15^{\circ} \mathrm{C}$ were nonpigmented, circular, slightly convex, bright and cream coloured with a diameter of $1 \cdot 0-1 \cdot 5 \mathrm{~mm}$. Cell wall structure was Gram-positive, as demonstrated by electron microscope examinations of ultra-thin sections (see Fig. Af, available as supplementary material in IJSEM Online), although results of the $\mathrm{KOH}$ test and the L-alanine aminopeptidase assay indicated a Gram-negative character. The isolate was facultatively anaerobic and grew at $4-31{ }^{\circ} \mathrm{C}$. Growth was optimal at $10-15{ }^{\circ} \mathrm{C}$. It grew in the presence of $4 \%(\mathrm{w} / \mathrm{v})$ $\mathrm{NaCl}$ and in $0.001 \%(\mathrm{w} / \mathrm{v})$ lysozyme, but not in $0 \cdot 1 \%(\mathrm{w} / \mathrm{v})$ lysozyme. The final $\mathrm{pH}$ in Voges-Proskauer broth after 7 days incubation at $15^{\circ} \mathrm{C}$ was less than $\mathrm{pH}$ 6. The isolate was negative for production of acetylmethylcarbinol, but positive for the methyl red reaction. Strain $20 \mathrm{CM}^{\mathrm{T}}$ did not decompose tyrosine. Phenotypic characteristics of the
Antarctic isolate and the closest phylogenetic relatives were compared (Table 1). Of the organisms compared, only strain $20 \mathrm{CM}^{\mathrm{T}}$ was positive for oxidase production. Phenotypic studies showed that the Antarctic isolate displayed characteristics consistent with those of the genus Paenibacillus (Ash et al., 1993).

Fatty acids were prepared from $40 \mathrm{mg}$ wet cell material harvested from a TSB agar $\left(30 \mathrm{~g} \mathrm{TSB}^{-1}, 15 \mathrm{~g}_{\text {agar }} \mathrm{l}^{-1}\right.$; $\left.\mathrm{BBL}\right)$ culture incubated for 4 days at $15^{\circ} \mathrm{C}$. The whole-cell fatty acids were determined as described previously by Bozal et al. (2002). Fatty acid analysis of $20 \mathrm{CM}^{\mathrm{T}}$ (Table A, available as supplementary material in IJSEM Online) revealed that anteiso- $\mathrm{C}_{15: 0}(55 \cdot 32 \%)$, iso- $\mathrm{C}_{15: 0}(15 \cdot 04 \%)$ and $\mathrm{C}_{16: 1} \omega 11 \mathrm{c}$ $(7 \cdot 72 \%)$ were predominant. This fatty acid profile was in accordance with that given in the description of the genus Paenibacillus (Ash et al., 1993). anteiso-Branched saturated $\mathrm{C}_{15: 0}$ is the predominant fatty acid found in all members of the genus Paenibacillus (Shida et al., 1997a).

Genomic DNA was prepared according to the method of Gevers et al. (2001). The G $+\mathrm{C}$ content was determined by HPLC as described by Mesbah et al. (1989). DNA-DNA relatedness was measured fluorometrically using the microplate hybridization method described by Ezaki et al. (1989). Determination of the 16S rRNA gene sequence of strain $20 \mathrm{CM}^{\mathrm{T}}$ and phylogenetic analyses were carried out as described previously by Bozal et al. (2002).

Phylogenetic studies based on 16S rRNA gene sequences confirmed that strain $20 \mathrm{CM}^{\mathrm{T}}$ is a member of the genus Paenibacillus (Fig. 1; Fig. B, available as supplementary material in IJSEM Online). The 16S rRNA gene sequence of strain $20 \mathrm{CM}^{\mathrm{T}}$ showed $99.5 \%$ similarity to that of Paenibacillus macquariensis DSM $2^{\mathrm{T}}$, which is significant enough to suggest possible species relatedness. Stackebrandt \& Goebel (1994) suggested that a sequence similarity value greater than $97 \%$ indicated conspecificity of the strains involved. The similarity values shown by $20 \mathrm{CM}^{\mathrm{T}}$ to other Paenibacillus type strains were under $97 \%$ (Paenibacillus borealis DSM $13188^{\mathrm{T}}, 95 \cdot 5 \%$; Paenibacillus odorifer LMG $19079^{\mathrm{T}}, 94 \cdot 7 \%$ ). To further verify the taxonomic position of isolate $20 \mathrm{CM}^{\mathrm{T}}$, DNA-DNA hybridizations were performed with P. macquariensis LMG $6935^{\mathrm{T}}$ (Marshall \& Ohye, 1966). The low DNA-DNA reassociation value of $47 \%$ between these two strains and the 16S rRNA gene sequence analysis confirmed the distinct position of strain $20 \mathrm{CM}^{\mathrm{T}}$ within the genus Paenibacillus. The $\mathrm{G}+\mathrm{C}$ content of strain $20 \mathrm{CM}^{\mathrm{T}}$ was $40 \cdot 7 \mathrm{~mol} \%$, which lies within the range observed for members of the genus Paenibacillus (Shida et al., 1997a).

Morphological, physiological, chemotaxonomic and phylogenetic data showed that strain $20 \mathrm{CM}^{\mathrm{T}}$ belongs to the genus Paenibacillus. DNA-DNA hybridization analysis clearly distinguished strain $20 \mathrm{CM}^{\mathrm{T}}$ from P. macquariensis (Marshall \& Ohye, 1966). Based on polyphasic evidence, it is proposed that strain $20 \mathrm{CM}^{\mathrm{T}}$ be assigned as the type strain of a novel species in the genus Paenibacillus, Paenibacillus antarcticus sp. nov. 
Table 1. Phenotypic characteristics that differentiate $P$. antarcticus $20 \mathrm{CM}^{\top}$ from its closest relatives in the genus Paenibacillus

Species: 1, P. antarcticus (data from this study); 2, Paenibacillus graminis (Berge et al., 2002); 3, Paenibacillus azotofixans (Seldin et al., 1984; Seldin \& Penido, 1986); 4, P. macquariensis (Marshall \& Ohye, 1966; Shida et al., 1997a, b; Elo et al., 2001); 5, P. borealis (Elo et al., 2001); 6, P. odorifer (Berge et al., 2002). All species produced acid from galactose, D-glucose, D-fructose, amygdalin, salicin, cellobiose, maltose, melibiose, sucrose, trehalose, D-raffinose, $\beta$-gentiobiose and D-turanose. None of the species produced acid from erythritol, D-arabinose, L-xylose, adonitol, L-sorbose, rhamnose, dulcitol, inositol, L-arabitol, 2-ketogluconate or 5-ketogluconate. All species were negative for growth at $42{ }^{\circ} \mathrm{C}$. For P. antarcticus, results are scored as positive or negative. For other species, results are scored as follows:,$+>90 \%$ strains positive;,$-<10 \%$ strains positive; $\mathrm{V}, 11-89 \%$ strains positive; ND, not determined.

\begin{tabular}{|c|c|c|c|c|c|c|}
\hline Characteristic & 1 & 2 & 3 & 4 & 5 & 6 \\
\hline Oxidase & + & - & - & - & - & - \\
\hline Voges-Proskauer test & - & $\mathrm{ND}$ & + & - & - & $\mathrm{ND}$ \\
\hline Production of dihydroxyacetone & - & $\mathrm{ND}$ & - & - & - & $\mathrm{ND}$ \\
\hline Casein hydrolysis & - & $\mathrm{ND}$ & - & - & + & $\mathrm{ND}$ \\
\hline \multicolumn{7}{|l|}{ Acid production from: } \\
\hline Glycerol & - & + & - & - & + & $\mathrm{v}$ \\
\hline $\begin{array}{l}\text { L-Arabinose, D-xylose, } \\
\text { methyl } \beta \text {-D-xyloside, } \\
N \text {-acetylglucosamine, lactose, starch }\end{array}$ & + & + & - & + & + & + \\
\hline Methyl $\alpha$-D-mannoside & - & - & - & + & - & - \\
\hline Methyl $\alpha$-D-glucoside & + & + & + & + & $\mathrm{v}$ & + \\
\hline Arbutin, glycogen & - & + & - & + & + & + \\
\hline Inulin & - & $\mathrm{v}$ & + & - & + & + \\
\hline Xylitol, D-lyxose, D-tagatose & - & - & - & - & $\mathrm{v}$ & - \\
\hline D-Fucose & - & $\mathrm{v}$ & - & - & - & - \\
\hline L-Fucose & - & - & - & + & - & $\mathrm{v}$ \\
\hline D-Arabitol & - & - & - & - & + & - \\
\hline Gluconate & - & $\mathrm{v}$ & - & + & - & - \\
\hline \multicolumn{7}{|l|}{ Growth at $\left({ }^{\circ} \mathrm{C}\right)$ : } \\
\hline 0 & - & - & - & + & - & - \\
\hline \multicolumn{7}{|l|}{ Growth in the presence of: } \\
\hline Lysozyme $(0 \cdot 001 \%)$ & + & $\mathrm{ND}$ & - & - & - & $\mathrm{ND}$ \\
\hline $\mathrm{NaCl}(5 \%)$ & - & ND & - & - & - & $\mathrm{ND}$ \\
\hline $\mathrm{G}+\mathrm{C}$ content $(\mathrm{mol} \%)$ & $40 \cdot 7$ & $52 \cdot 1$ & $51 \cdot 6$ & 39 & $53 \cdot 6$ & $44 \cdot 0$ \\
\hline
\end{tabular}

\section{Description of Paenibacillus antarcticus}

Paenibacillus antarcticus (ant.arc'ti.cus. L. masc. adj. antarcticus of the Antarctic environment, where the organism was isolated).

Cells are rod-shaped $(0 \cdot 7 \times 2.5 \mu \mathrm{m})$ and motile by means of peritrichous flagella. Subterminal or terminal ellipsoidal spores are formed in swollen sporangia. Colonies grown on TSA are non-pigmented, circular, slightly convex, bright and cream coloured. Cells are facultatively anaerobic and stain Gram-variable. Growth is not inhibited by the presence of $4 \% \mathrm{NaCl}$ or $0.001 \%$ lysozyme. Growth occurs at 4 and 


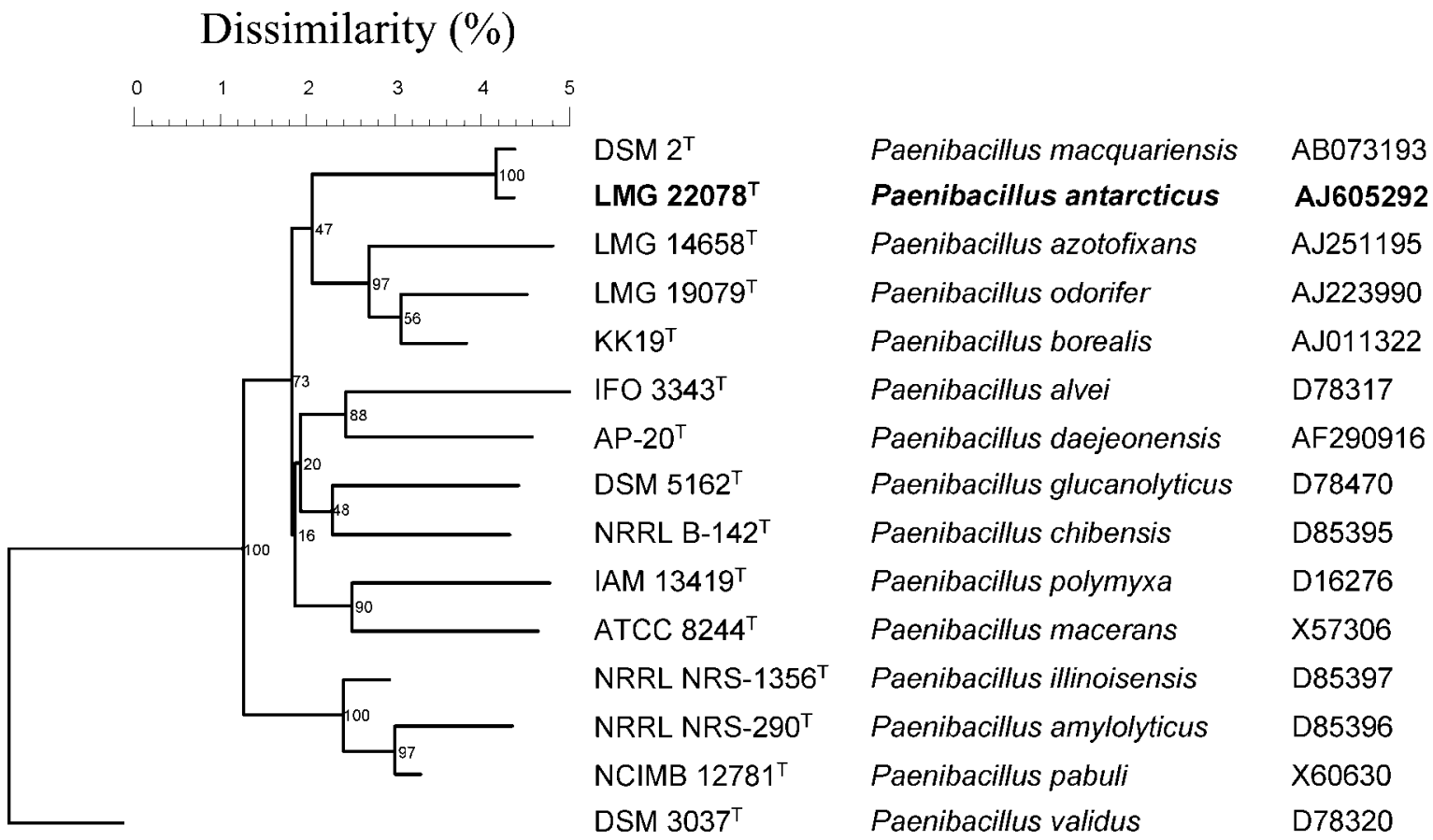

Fig. 1. Phylogenetic position of strain $20 \mathrm{CM}^{\top}$ among neighbouring species of the genus Paenibacillus, based on $16 \mathrm{~S}$ rRNA gene sequence analysis. Bootstrap values are indicated.

$31{ }^{\circ} \mathrm{C}$, but not at 0 or $32^{\circ} \mathrm{C}$; optimal growth occurs at $10-15^{\circ} \mathrm{C}$. Oxidase, catalase, urease and methyl red reactions are positive. Nitrate reduction, Voges-Proskauer reaction, $\beta$-galactosidase, arginine dihydrolase, lysine decarboxylase, ornithine decarboxylase, citrate utilization, dihydroxyacetone production, indole production, $\mathrm{H}_{2} \mathrm{~S}$ production, phenylalanine deamination and tryptophan deaminase are negative. Aesculin, starch and Tween 80 are hydrolysed. Does not hydrolyse casein, lecithin, gelatin, DNA or tyrosine. With API systems, acid is produced from $\mathrm{L}$-arabinose, ribose, $\mathrm{D}$-xylose, methyl $\beta$-D-xyloside, galactose, $\mathrm{D}$-glucose, $\mathrm{D}$-fructose, $\mathrm{D}$ mannose, methyl $\alpha$-D-glucoside, $N$-acetylglucosamine, amygdalin, aesculin, salicin, cellobiose, maltose, lactose, melibiose, sucrose, trehalose, D-raffinose, starch, $\beta$-gentiobiose and Dturanose. Acid is not produced from glycerol, erythritol, D-arabinose, L-xylose, adonitol, L-sorbose, rhamnose, dulcitol, inositol, mannitol, sorbitol, methyl $\alpha$-D-mannoside, arbutin, inulin, melezitose, glycogen, xylitol, D-lyxose, D-tagatose, D-fucose, L-fucose, D-arabitol, L-arabitol, gluconate, 2ketogluconate or 5-ketogluconate. The predominant fatty acid is anteiso- $\mathrm{C}_{15: 0}(55 \cdot 32 \%)$.

The type strain is $20 \mathrm{CM}^{\mathrm{T}}\left(=\mathrm{LMG} 22078^{\mathrm{T}}=\right.$ CECT $\left.5836^{\mathrm{T}}\right)$; its $\mathrm{G}+\mathrm{C}$ content is $40 \cdot 7 \mathrm{~mol} \%$.

\section{Acknowledgements}

We would like to thank Josefina Castellví for providing Antarctic samples. We gratefully acknowledge the assistance of F. Garcia (Departament d'Agricultura, Ramaderia i Pesca, Generalitat de Catalunya, Spain) with the fatty acid analysis. We thank the
Technical Scientific Services of Barcelona University (Unitat de Microscopia Electrònica) for assistance. We acknowledge the BCCM/LMG Identification Service (LMG, BCCM/LMG Bacteria Collection, Laboratorium voor Microbiologie, University Ghent, Ghent, Belgium) for performing the hybridization analysis and $16 \mathrm{~S}$ rRNA gene sequence analysis. This work was supported by grant 2001SGR 00126 Generalitat de Catalunya.

\section{References}

Ash, C., Priest, F. G. \& Collins, M. D. (1993). Molecular identification of rRNA group 3 bacilli (Ash, Farrow, Wallbanks and Collins) using a PCR probe test. Proposal for the creation of a new genus Paenibacillus. Antonie Van Leeuwenhoek 64, 253-260.

Berge, O., Guinebretière, M.-H., Achouak, W., Normand, P. \& Heulin, T. (2002). Paenibacillus graminis sp. nov. and Paenibacillus odorifer sp. nov., isolated from plant roots, soil and food. Int J Syst Evol Microbiol 52, 607-616.

Bozal, N., Montes, M. J., Tudela, E., Jiménez, F. \& Guinea, J. (2002). Shewanella frigidimarina and Shewanella livingstonensis sp. nov. isolated from Antarctic coastal areas. Int J Syst Evol Microbiol 52, 195-205.

Chung, Y. R., Kim, C. H., Hwang, I. \& Chun, J. (2000). Paenibacillus koreensis sp. nov., a new species that produces an iturin-like antifungal compound. Int J Syst Evol Microbiol 50, 1495-1500.

Claus, D. \& Berkeley, R. C. W. (1986). Genus Bacillus Cohn 1872, $174^{\mathrm{AL}}$. In Bergey's Manual of Systematic Bacteriology, vol. 2, pp. 1105-1139. Edited by P. H. A. Sneath, N. S. Mair, M. E. Sharpe \& J. G. Holt. Baltimore: Williams \& Wilkins.

Cowan, S. T. \& Steel, K. J. (1993). Manual for the Identification of Medical Bacteria, 3rd edn. Edited and revised by G. I. Barrow \& R. K. A. Feltham. Cambridge: Cambridge University Press. 
Elo, S., Suominen, I., Kämpfer, P., Juhanoja, J., Salkinoja-Salonen, M. \& Haahtela, K. (2001). Paenibacillus borealis sp. nov., a nitrogenfixing species isolated from spruce forest humus in Finland. Int J Syst Evol Microbiol 51, 535-545.

Ezaki, T., Hashimoto, Y. \& Yabuuchi, E. (1989). Fluorometric deoxyribonucleic acid-deoxyribonucleic acid hybridization in microdilution wells as an alternative to membrane filter hybridization in which radioisotopes are used to determine genetic relatedness among bacterial strains. Int J Syst Bacteriol 39, 224-229.

Fortina, M. G., Pukall, R., Schumann, P., Mora, D., Parini, C., Manachini, P. L. \& Stackebrandt, E. (2001). Ureibacillus gen. nov., a new genus to accommodate Bacillus thermosphaericus (Andersson et al. 1995), emendation of Ureibacillus thermosphaericus and description of Ureibacillus terrenus sp. nov. Int J Syst Evol Microbiol 51, 447-455.

Gevers, D., Huys, G. \& Swings, J. (2001). Applicability of rep-PCR fingerprinting for identification of Lactobacillus species. FEMS Microbiol Lett 205, 31-36.

Heyndrickx, M., Vandemeulebroecke, K., Scheldeman, P. \& 7 other authors (1995). Paenibacillus (formerly Bacillus) gordonae (Pichinoty et al. 1986) Ash et al. 1994 is a later subjective synonym of Paenibacillus (formerly Bacillus) validus (Nakamura 1984) Ash et al. 1994: emended description of P. validus. Int J Syst Bacteriol 45, 661-669.

Heyndrickx, M., Vandemeulebroecke, K., Hoste, B., Janssen, P., Kersters, K., De Vos, P., Logan, N. A., Ali, N. \& Berkeley, R. C. W. (1996a). Reclassification of Paenibacillus (formerly Bacillus) pulvifaciens (Nakamura 1984) Ash et al. 1994, a later subjective synonym of Paenibacillus (formerly Bacillus) larvae (White 1906) Ash et al. 1994, as a subspecies of $P$. larvae, with emended descriptions of $P$. larvae as $P$. larvae subsp. larvae and $P$. larvae subsp. pulvifaciens. Int J Syst Bacteriol 46, 270-279.

Heyndrickx, M., Vandemeulebroecke, K., Scheldeman, P., Kersters, K., De Vos, P., Logan, N. A., Aziz, A. M., Ali, N. \& Berkeley, R. C.W. (1996b). A polyphasic reassessment of the genus Paenibacillus, reclassification of Bacillus lautus (Nakamura 1984) as Paenibacillus lautus comb. nov. and of Bacillus peoriae (Montefusco et al. 1993) as Paenibacillus peoriae comb. nov., and emended descriptions of P. lautus and of P. peoriae. Int J Syst Bacteriol 46, 988-1003.

Heyndrickx, M., Lebbe, L., Kersters, K., De Vos, P., Forsyth, G. \& Logan, N. A. (1998). Virgibacillus: a new genus to accommodate Bacillus pantothenticus (Proom and Knight 1950). Emended description of Virgibacillus pantothenticus. Int J Syst Bacteriol 48, 99-106.

Hucker, G. J. \& Conn, H. J. (1923). Methods of Gram staining. Technical Bulletin of the New York State Agricultural Experimental Station, no. 93.

Kanzawa, Y., Harada, A., Takeuchi, M., Yokota, A. \& Harada, T. (1995). Bacillus curdlanolyticus sp. nov. and Bacillus kobensis sp. nov., which hydrolyse resistant curdlan. Int J Syst Bacteriol 45, 515-521.

Logan, N. A., Lebbe, L., Hoste, B. \& 7 other authors (2000). Aerobic endospore-forming bacteria from geothermal environments in northern Victoria Land, Antarctica, and Candlemas Island, South Sandwich archipelago, with the proposal of Bacillus fumarioli sp. nov. Int J Syst Evol Microbiol 50, 1741-1753.

Logan, N. A., Lebbe, L., Verhelst, A., Goris, J., Forsyth, G., Rodriguez-Diaz, M., Heyndrickx, M. \& De Vos, P. (2002). Bacillus luciferensis sp. nov., from volcanic soil on Candlemas Island, South Sandwich archipelago. Int J Syst Evol Microbiol 52, 1985-1989.

Logan, N. A., Lebbe, L., Verhelst, A., Goris, J., Forsyth, G., Rodriguez-Díaz, M., Heyndrickx, M. \& De Vos, P. (2004a). Bacillus shackletonii sp. nov., from volcanic soil on Candlemas Island, South Sandwich archipelago. Int J Syst Evol Microbiol 54, 373-376.

Logan, N. A., De Clerck, E., Lebbe, L., Verhelst, A., Goris, J., Forsyth, G., Rodríguez-Díaz, M., Heyndrickx, M. \& De Vos, P. (2004b).
Paenibacillus cineris sp. nov. and Paenibacillus cookii sp. nov., from Antarctic volcanic soils and a gelatin-processing plant. Int J Syst Evol Microbiol 54 (in press).

Manafi, M. \& Kneifel, W. (1990). Rapid methods for differentiating gram-positive from gram-negative aerobic and facultative anaerobic bacteria. J Appl Bacteriol 69, 822-827.

Marshall, B. J. \& Ohye, D. F. (1966). Bacillus macquariensis n. sp., a psychrotrophic bacterium from sub-Antarctic soil. J Gen Microbiol 44, 41-46.

Mesbah, M., Premachandran, U. \& Whitman, W. B. (1989). Precise measurement of the $\mathrm{G}+\mathrm{C}$ content of deoxyribonucleic acid by high-performance liquid chromatography. Int J Syst Bacteriol 39, 159-167.

Nakamura, L. K. (1987). Bacillus alginolyticus sp. nov. and Bacillus chondroitinus sp. nov., two alginate-degrading species. Int J Syst Bacteriol 37, 284-286.

Nazina, T. N., Tourova, T. P., Poltaraus, A. B. \& 8 other authors (2001). Taxonomic study of aerobic thermophilic bacilli: descriptions of Geobacillus subterraneus gen. nov., sp. nov. and Geobacillus uzenensis sp. nov. from petroleum reservoirs and transfer of Bacillus stearothermophilus, Bacillus thermocatenulatus, Bacillus thermoleovorans, Bacillus kaustophilus, Bacillus thermoglucosidasius and Bacillus thermodenitrificans to Geobacillus as the new combinations G. stearothermophilus, G. thermocatenulatus, G. thermoleovorans, G. kaustophilus, G. thermoglucosidasius and G. thermodenitrificans. Int J Syst Evol Microbiol 51, 433-446.

Niimura, Y., Koh, E., Yanagida, F., Suzuki, K.-I., Komagata, K. \& Kozaki, M. (1990). Amphibacillus xylanus gen. nov., sp. nov., a facultatively anaerobic sporeforming xylan-digesting bacterium which lacks cytochrome, quinone, and catalase. Int J Syst Bacteriol 40, 297-301.

Pettersson, B., Rippere, K. E., Yousten, A. A. \& Priest, F. G. (1999). Transfer of Bacillus lentimorbus and Bacillus popilliae to the genus Paenibacillus with emended descriptions of Paenibacillus lentimorbus comb. nov. and Paenibacillus popilliae comb. nov. Int J Syst Bacteriol 49, 531-540.

Priest, F. G., Goodfellow, M. \& Todd, C. (1988). A numerical classification of the genus Bacillus. J Gen Microbiol 134, 1847-1882.

Schlesner, H., Lawson, P. A., Collins, M. D., Weiss, N., Wehmeyer, U., Völker, H. \& Thomm, M. (2001). Filobacillus milensis gen. nov., sp. nov., a new halophilic spore-forming bacterium with Orn-D-Glu-type peptidoglycan. Int J Syst Evol Microbiol 51, 425-431.

Seldin, L., Van Elsas, J. D. \& Penido, E. G. C. (1984). Bacillus azotofixans sp. nov., a nitrogen-fixing species from Brazilian soils and grass roots. Int J Syst Bacteriol 34, 451-456.

Seldin, L. \& Penido, E. G. C. (1986). Identification of Bacillus azotofixans using API tests. Antonie Van Leeuwenhoek 52, 403-409.

Shida, O., Takagi, H., Kadowaki, K. \& Komagata, K. (1996). Proposal for two new genera, Brevibacillus gen. nov. and Aneurinibacillus gen. nov. Int J Syst Bacteriol 46, 939-946.

Shida, O., Takagi, H., Kadowaki, K., Nakamura, L. K. \& Komagata, K. (1997a). Transfer of Bacillus alginolyticus, Bacillus chondroitinus, Bacillus curdlanolyticus, Bacillus glucanolyticus, Bacillus kobensis, and Bacillus thiaminolyticus to the genus Paenibacillus and emended description of the genus Paenibacillus. Int J Syst Bacteriol 47, 289-298.

Shida, O., Takagi, H., Kadowaki, K., Nakamura, L. K. \& Komagata, K. (1997b). Emended description of Paenibacillus amylolyticus and description of Paenibacillus illinoisensis sp. nov. and Paenibacillus chibensis sp. nov. Int J Syst Bacteriol 47, 299-306.

Slepecky, R. A. \& Hemphill, H. E. (1991). The genus Bacillus nonmedical. In The Prokaryotes, pp. 1663-1696. Edited by A. Balows, 
H. G. Trüper, M. Dworkin, W. Harder \& K. H. Schleifer. New York: Springer.

Spring, S., Ludwig, W., Marquez, M. C., Ventosa, A. \& Schleifer, K.-H. (1996). Halobacillus gen. nov., with description of Halobacillus litoralis sp. nov. and Halobacillus truperi sp. nov., and transfer of Sporosarcina halophilia to Halobacillus halophilus comb. nov. Int J Syst Bacteriol 46, 492-496.

Stackebrandt, E. \& Goebel, B. M. (1994). Taxonomic note: a place for DNA-DNA reassociation and 16S rRNA sequence analysis in the present species definition in bacteriology. Int J Syst Bacteriol 44, 846-849.

van der Maarel, M. J. E. C., Veen, A. \& Wijbenga, D. J. (2000). Paenibacillus granivorans sp. nov., a new Paenibacillus species which degrades native potato starch granules. Syst Appl Microbiol 23, 344-348.

Wainø, M., Tindall, B. J., Schumann, P. \& Ingvorsen, K. (1999). Gracilibacillus gen. nov., with description of Gracilibacillus halotolerans gen. nov., sp nov.; transfer of Bacillus dipsosauri to Gracilibacillus dipsosauri comb. nov., and Bacillus salexigens to the genus Salibacillus gen. nov., as Salibacillus salexigens comb. nov. Int J Syst Bacteriol 49, 821-831.

Wisotzkey, J. D., Jurtshuk, P., Jr, Fox, G. E., Deinhard, G. \& Poralla, K. (1992). Comparative sequence analyses on the 16S rRNA (rDNA) of Bacillus acidocaldarius, Bacillus acidoterrestris, and Bacillus cycloheptanicus and proposal for creation of a new genus, Alicyclobacillus gen. nov. Int J Syst Bacteriol 42, 263-269. 